\title{
CECÍlia donNANGELO hOJE
}

Rtcardo Bruno Mendes Gonçalves*

Há pouco mais do que nove anos, de modo prematuro e trágico, Cecília Donnangelo encerrava sua participação direta na história das práticas de saúde no Brasil. Pela extraordinária importancia que teve essa participação, é justo que se aproveite a oportunidade, tão cercada de esperanças, do lançamento de uma publicação regular na área de trabalho na qual viveu toda sua militância, para lembrá-la e lembrar o alcance de sua contribuição. $O$ sentido histórico do que temos para comemorar - um começo, um nascimento - tal como deveria ser apreendido e avaliado pelo pensamento de Cecília, me impõe cuidados que não estou certo de bem poder tomar, pois creio que andaria pelo avesso desse pensamento se sugerisse que sua apreciação se reduzisse à que se faz acerca do "vulto histórico", se induzisse a tomá-lo como um símbolo petrificado, cujo aparente vigor só é tão grande quanto sua capacidade de nos impedir a percepção adequada de nossa própria situação no movimento histórico.

No espírito dessas palavras, deixo propositalmente de lado qualquer tentativa de recensear, mesmo que superficialmente, os fatos que marcaram sua notável participação direta em nossa história, para ousar tentar identificá-la viva ainda hoje, no que creio que ela própria julgaria ser a dimensão mais significativa de sua individualidade especificamente humana, a dimensão em que se integra em uma consciencia e em uma prática que vão além de sua vida particular e do seu tempo delimitado de existencia, para estender-se por vidas e tempos necessariamente plurais.

Nesse ambito alargado, e tomando seu trabalho parcialmente, apenas como trabalho de cientista social, julgo que, de algumas das teses que sustentou, delas se pode dizer o que afinal caracteriza os pensadores: quer aceitando-as como elas as deixou, quer fazendo abstraçăo de seus conteúdos concretos, que sejam por isso necessariamente datados, quer mesmo quando

- Docente do Departamento de Medicina Preventiva da Faculdade de Medicina da Universidade de Sáo Paulo. 
esses conteúdos particulares devam ser postos em dúvida, por referência à sua satisfatoriedade explicativa, em todos esses casos evidencia-se que sua dimensão teórica permanece viva e fecunda.

O esforço que Cecília Donnangelo empreendeu para que se pudesse, no Brasil, compreender e explicar, apreender e transformar as práticas de saúde, especialmente a prática médica, tomando-as como práticas constitutivas da socialidade - e esta é a sua grande tese - fundamentou, e fundamenta ainda, um amplo conjunto de investigaçōes científicas e de aplicações técnicas e políticas que acabou por levar a vida quotidiana do trabalhador em saúde a um novo estágio de objetivação. Eis aí o indicador máximo da excelência do pensamento teórico: retornar à quotidianidade, constituindo as identidades sociais particulares das pessoas em sua vida comum, sem que elas suspeitem que as categorias mentais à base das quais procedem a essa construção tenham sido arduamente arrancadas das aparencias e dos preconceitos em tempos anteriores. Nada mais seria preciso para demonstrar que o pensamento teórico de Cecília Donnangelo se incorporou à herança da humanidade e que, nesse sentido, ela permanece viva.

Mesmo em esferas superiores de objetivação, onde se dá o debate político, a vitalidade de seu pensamento se evidencia ainda, e antes de tudo por sua relação com os que seriam seus adversários: estes podem, conhecendo ou não a origem das teses contra as quais se colocam, contrariá-las efetivamente, mas não podem de modo algum ignorá-las, voltando a um modo de pensamento e ação que imperavam antes dos anos 70. A superioridade indicada por esse fato não deve sugerir que ela fosse apenas possuidora de uma inteligência mais penetrante e produtiva, idéla que lhe inspiraria repugnancia, mas que seu trabalho como ser humano genérico, pelo esforço consciente na busca racional da Verdade trouxe-a, e trouxe-a juntamente com seus adversários, a uma etapa superior de racionalidade.

Na dimensão de educadora e militante de seu trabalho, inteiramente solidária da de investigadora, é que se revelou melhor a grandeza de seu exemplo. Pois todos que convivemos com ela aprendemos uma liçăo que se pode aproveitar mal, mas não se pode esquecer: a busca racional da Verdade é indissociável da busca do Bem. O apaixonado vigor com que se lançava à defesa do rigor metodológico encontrava sua justificaçăo profunda na conexão entre o Bem e a busca da Verdade; a emocionante indignaçăo com que 
colocava o amor pela humanidade acima de qualquer Verdade teórica fundamentava a justa relação entre ambos. Em algumas gerações de alunos e companheiros ficou gravada essa postura ética como um imperativo de consciência absolutamente irrenunciável.

Pela força de sua presença, agora mediada pelas práticas de toda uma multidão de trabalhadores em saúde que ajudou a formar, direta e indiretamente, Cecília Donnangelo é um dos pilares sobre os quais se constitui a Saúde Coletiva brasileira como área de trabalho vividamente atenta às relações entre as pulsações dos compromissos sociais e as exigências da seriedade profissional.

Enquanto assim for, ela permanece viva. Que as páginas desta revista possam contribuir para a permanência dessa tradição. 